\title{
SOLITARY FIBROUS TUMOUR OF PLEURA
}

\author{
Wg Cdr YM SIRPAL
}

MJAFI 2002; 58 : 76-77

KEY WORDS :Fibrous tumour of pleura.

\section{Introduction}

$\mathbf{S}$ olitary fibrous tumour of the pleura is an uncommon tumour [1]. It is not linked to exposure to asbestos [2]. Most cases are asymptomatic. This paper presents one such uncommon case. Relevant literature is briefly reviewed.

\section{Case Report}

A 40 year old male patient reported with vague complaints of feeling progressively increasing heaviness, constriction of the right side of chest and frequent episodes of cough. Clinical examination of lungs was non-contributory. There was no evidence of osteourthropathy, anaemia and clubbing of nails. Routine haematological and biochemical parameters were within normal limits. Chest skiagrams revealed an irregular, dense opacity in right mid zone. There was no cardiomegaly. Fine needle aspiration cytology revealed low-cell-yielding smears with a few spindle shaped cells. No cellular atypia and mitotic figures were present.

On thoracotomy, a sessile, an irregularly thickened, firm, grey white mass (maximum thickness $2 \mathrm{cms}$ ), parially encapsulated. measuring $10.5 \mathrm{cms}$ in maximum dimensions was noted. The mass was seen covering the anterolateral surface of right middle lobe and was lying in the interlobar fissure separating the right middle and upper lobes. On separation of the tumour from underlying lung, it was seen invading the lung parenchyma of right upper lobe. Tumour mass with affected part of right lung was removed en-masse.

Cut surfaces of the tumour appeared grey white with frequent whorling and fasciculation resembling that of uterine fibroid. Microscopic examination revealed tumour tissue comprising spindle cells intermingled with thick collagen bundles in a random arrangement (Fig-1). Storiform pattern was not observed. Focal areas of myxomatous degeneration were noted. Mitotic figures were infrequent. Tumour tissue was also seen infiltrating and widening the interalveolar septae in lung parenchyma (Fig-2). However, no area of necrosis was present. A diagnosis of solitary fibrous tumour of pleura was made. The patient was followed up for 3 years. There was no recurrence of the tumour.

\section{Discussion}

Solitary fibrous tumour of pleura, formerly called fibrous mesothelioma of pleura, is uncommon. Tumour may be found attached to the visceral pleura in four-fifths of the cases and to the parietal pleura in the remainder. Only in a few cases, tumour originates from interlobar fissure or even wholly in the lung pa- renchyma [3]. It commonly appears pedunculated and measures several centimetres across [2]. It can be easily shelled out being well circumscribed and encapsulated. Microscopic appearance of admixture of spindle cells and mature collagen are common. Mitotic figures are few and areas of degeneration are occasional. Increased cellularity, atypia, frequent mitotic figures, large size and necroses are features commonly associated with aggressive behaviour [1-5]. In the present case, the tumour involved horizontal interlobar

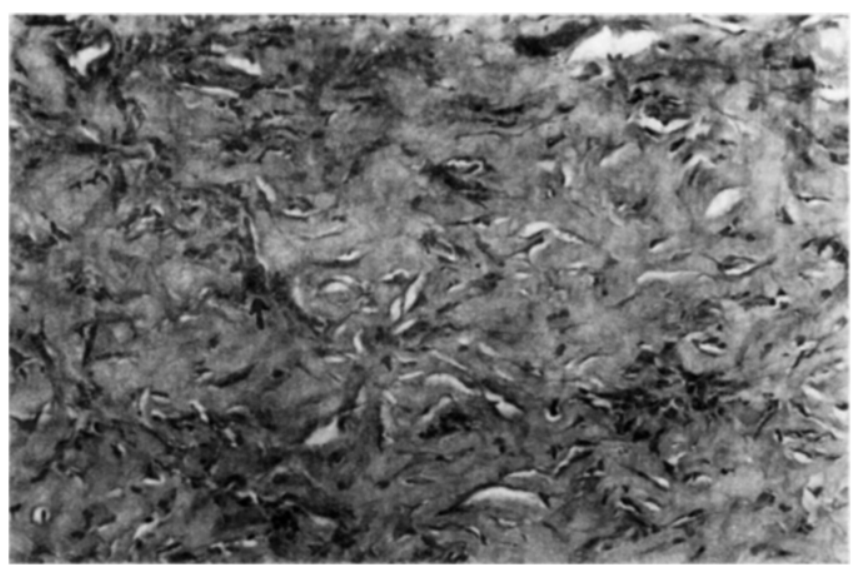

Fig. 1: Spindle cells intermingled with thick collagen bundles in random arrangement. Arrow indicates a mitotic figure (H\&E x 400)

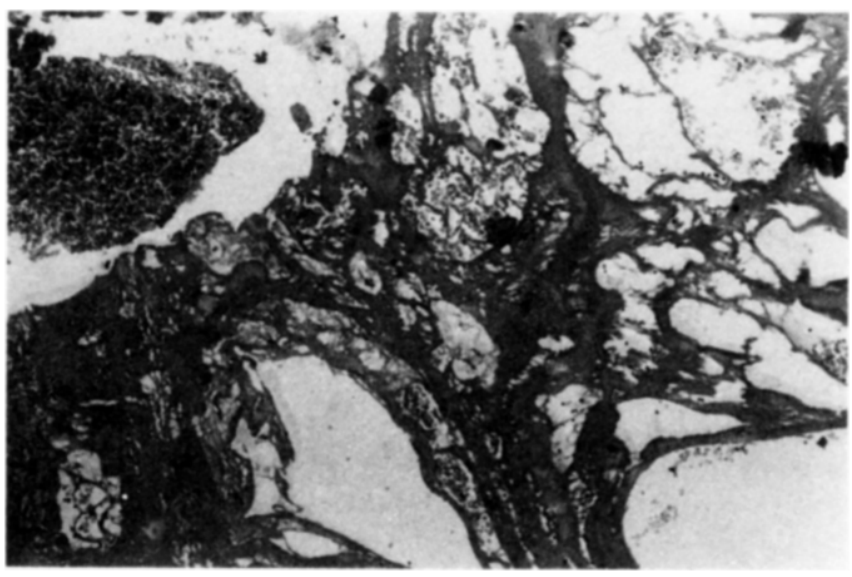

Fig. 2 : Fibrous tumour of pleura extending into lung parenchyma widening interalveolar septae (H\&E x 200) 
fissure and visceral pleura with extension into right upper lobe of lung. Microscopically, it depicted the characteristic features. There was no evidence oi aggressive behaviour.

Patients with localized fibrous tumour of pleura are usually over 40 years but it has also been described in children [2]. Immunohistochemical and ultrastructural evidences suggest that the tumour cells arise from non-committed mesenchymal cells present in the areolar tissue subjacent to the mesothelial lining [2,6] which stain strongly for vimetin and CD 34 [2,6,7]. A few of these tumours are associated with hypoglycaemia [8] or osteoarthropathy [2], which remits when tumour is excised. The present case had no such associated manifestation.

\section{References}

1. Barker F, Krausz T. The pleura. In : Mc-Gee J O'D, Isaacson PG, Wright NA editors. Oxford textbook of pathology: Pathology of systems. Oxford University Press, 1992;1043-4.

2. Rosai J. Lung and Pleura. In : Ackerman's Surgical Pathol- ogy. St Louis : Mosby year Book, Inc, 1996;342-3.

3. Yousem SA, Flynn SD. Intrapulmonary localized fibrous tumour. Intraparenchmyal, so-called loalized fibrous mesothelioma. Am J Clin Pathol 1988; 88 : 365-9.

4. England DM, Hochholzer L, Mc Carthy MJ. Localized benign and malignant fibrous tumours of the pleura:a clinicopathological review of 223 cases. Am J Surg Pathol 1989;13(8):640-58.

5. Brisellim M. Mark EJ, Dickersin GR. Solitary fibrous tumour of the pleura : 8 new cases and review of 360 cases in the literature. Cancer 1981:47:2678-89.

6. Steinietz C, Clarke R, Jacobs GH, Abdul Karim FN, Petrelli $M$, Tomashefski JF. Localised fibrous tumours of the pleura. Correlation of histopathologial, immunohistochemical and ultra structural features. Pathol Res Pract 1990;186:344-57.

7. Flint A, Weiss SW. CD 34 and keratin expression distinguished solitary fibrous tumour (fibrous mesothelioma) of pleura from desmoplastic mesothelioma. Hum Pathol 1995;26:428-31.

8. Spry CJF, Willianson DH, James ML. Pleural mesotheliomas and hypoglyacaemia. Proc Roy Soc Med 1968:61:1 105-10. 